Discourse and Communication for Sustainable Education, vol. 5, pp. 31-37, 2014

\title{
The Future Architects' Attitude towards Innovations in the Context of Sustainable Development
}

\author{
Veronika Artemeva \\ Saint-Petersburg State University of Architecture and Civil Engineering, Russia
}

\begin{abstract}
The architectural innovations are becoming more and more important in the economic and social development and in the quality improvement of people's lives. Sometimes, however, the implementation of innovative projects can lead to negative consequences. The development of any innovation should be based on a comprehensive analysis of their implementation's consequences. Therefore, developing a responsible of the future architects' attitude to innovations is extremely important for achieving a qualitatively new level of training of future architects to ensure sustainable development. This article presents the results of a research that investigated the social values of future architects and their attitude towards innovation.
\end{abstract}

Keywords: sustainable development, innovation, social values, responsibility, professional ethics

Today Russia is introducing new approaches to education in high school, educational stereotypes are changing, and professional activity is becoming more and more complicated. While training the future specialists, we should think about the professional component of their education in the first place (Andreas \& Strannegård, 2014). This is absolutely true. It is essential that our graduates are truly professional. However, the attitude to knowledge and innovation and the ability to use them in different situations, the values and ethical aspects of the evaluation of innovations, in our opinion, are crucial for the formation of a true professional and for the sustainable development of the educational system in general. Nevertheless, not all the educational institutions have the necessary social, technical and scientific basis that promotes understanding, evaluation and acceptance (or non-acceptance) of the innovation processes (Artemeva, 2012).

Typically, innovations are developed and intruded in order to improve the quality of life. However, the possibility of negative consequences is not always taken into account. For example, such negative consequences as environmental, demographic and cultural problems are not taken into consideration. Any innovation has its own carriers, its own social basis. The development of the society depends on the younger generation in general and on each young person individually. However, at present a large number of classes, especially the humanities in technical universities, are considered to be studied by the 
students on their own, which reduces the possibility of deep analysis of various situations, including psychological and educational problems (Abedalaziz, 2012). But valuable moral self-determination problems of students do not become less important (Veselova, 2012). They take on special significance in the direction of sustainable development in education (Salìte, Gedžūne, \& Gedžūne, 2009). Therefore, in our opinion, the need to examine the attitudes of the students towards innovation processes appears.

The term "innovation" is of Latin origin. The Romans understood innovation as "change" and "renewal" in the broad sense of the word. Innovation is a concept with a broad content, including the economic, engineering, philosophical, psychological and social category (Yushkov, 2008). Innovation in general can be seen as a person's ability to perceive, extract, refine and intrude new and original ideas (Yagolkovsky, 2010).

Native and foreign psychologists conducted theoretical and empirical studies of various aspects of innovation (Autio, Kenney, Mustar, Siegel, \& Wright, 2014; Kirton, 2003; Plotinskiy, 2001; Sovetova, 2000; Yagolkovsky, 2010) and others. The result of their work suggests multifactorial nature of innovation and the need for a comprehensive opinion of psychological preparedness of the different social groups of citizens to different kinds of innovation, including social.

One of the components of this opinion is to assess one's own system of values.

The values are included in the structure of personality and are in essence the core of its orientation, defining ideology and moral positions. The system of values is formed by the end of high school. It becomes different after serious changes in a person's life. When these changes do not appear, the system of values demonstrates the relative stability, predetermining the degree of complexity of people's inclusion in different social situation or culture, as well as the depth of this inclusion. In some cases it does not hinder, and sometimes it even facilitates the human's adaptation to changes in one's life, but in other cases it can make the adaptation much more complicated.

In our research, we relied on the concept of social values, which was defined by Godlinik (2001) this way:

Social values are material and social objects, which are significant for the individual, the social community and the society in general, the spiritual human activity and its results; socially approved and shared by most people's idea of what is good, what justice, patriotism, romantic love, friendship and so on are. They are not the subjects to doubt as they serve as standards, ideal for all people; the pedagogical process is aiming at their formation (p.127).

\section{Research Objectives}

The main goal of our research is to study the attitude of future architects towards innovation.

The research was held in two phases:

- The value orientations of the students of the architectural faculty of St. Petersburg State University of Architecture and Civil Engineering were researched in the first stage;

- The attitude of students towards innovation was researched in the second stage. 


\section{Method}

The respondents of the study - the 4th year students of St. Petersburg State University of Architecture and Civil Engineering, Faculty of Architecture, altogether 84 people aged 19 to 25 years, including 45 boys and 39 girls.

The research methods:

- modified inquirer that detects the value orientations by Mikael Gornyi (Artemeva, 2012);

- the evaluation method of the attitude towards innovations (Artemeva, 2012);

- the interview, which was given the task to briefly describe the experience of scanned material and to analyse the possible consequences of the introduction of these innovative achievements (Artemeva, 2012);

- conversation and methods of mathematical statistics.

\section{Research Findings}

According to the analysis of the data, one can see that the main priorities for the students (both girls and boys) are family $(68 \%)$ and freedom $(38 \%)$.

Family serves as a bulwark of security and happiness. Family can make one feel both safe and truly free. It should be noted that the orientation of modern students are changing from the free relationship to the creation of family.

The result for the second position (freedom) was predicted for us. Throughout this research, we expected to get a standard answer, which is given by the respondents in democratic countries $-40 \%$ of the respondents choose freedom as a priority. Our data are very similar $-38 \%$ of the respondents and the second position in the rating.

But the values that stand in the third position are different for the young men and women. Girls choose security as a value $(28 \%)$. For the young men, wealth $(32 \%)$ plays an important role in their life.

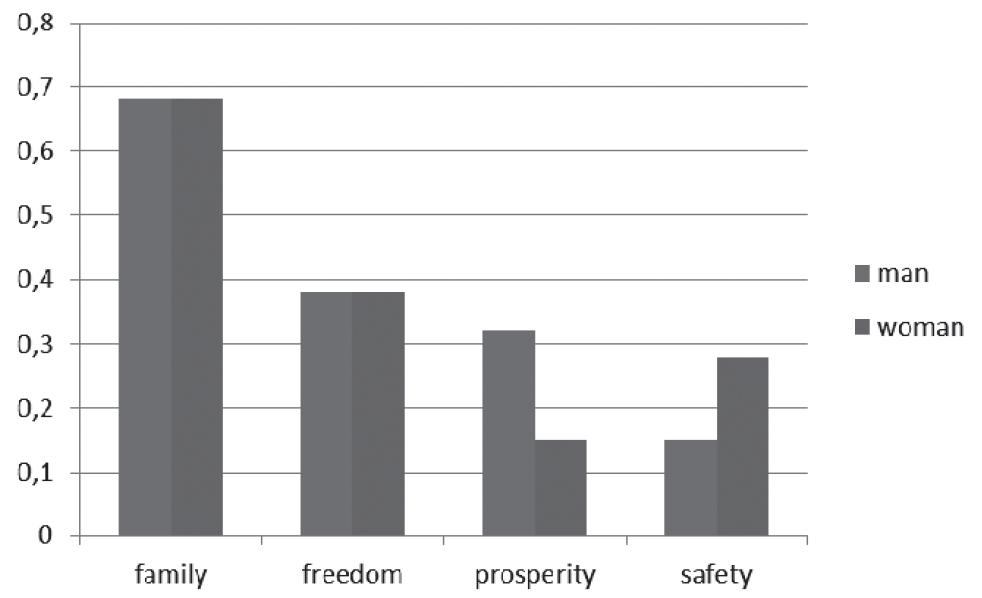

Figure 1. The top values of the students of Saint-Petersburg State University of Architecture and Civil Engineering

We should note that the students of St. Petersburg State University of Architecture and Civil Engineering consider such values as democracy and power to be at the bottom. 
Almost half of the respondents $(49 \%)$ showed their willingness to leave the country. It is interesting that our results are almost the same compared with the results of the research by Lesovichenko (2008), which was held in STU and with the results of research which are carried out by author (Artemeva, 2012). The only exception is the indicators of family values.

Thus, we can see that students of all universities face the same the moral problems. But the question how to solve them still does not have an exact answer.

Therefore, we lead the second phase of the research - the study of the students' attitudes towards innovations.

We used the method of evaluation of the attitude towards innovations (Artemeva, 2012; Artemeva, 2013) aimed at studying the preferred changes, identification of causes of different attitudes to innovation and determination of the motives of innovative behaviour.

The study revealed a difference in students' preferences to the changes that take place in different spheres of life and work.

Thus, young men believe that the changes are quite necessary in science $(40.3 \%)$ in their personal aspirations and personal growth $(33.3 \%)$, in changes of the existing situation in the country $(21.3 \%)$. Girls feel that changes are necessary in a career in the first place $(49.9 \%)$, in the second place - in one's own development (education, spiritual growth, cultural development) $(28 \%)$, and only after that - the changes in the family $(20.7 \%)$, in an aids and appliances $(10.7 \%)$ (The areas in which it is necessary to make changes, according to the opinion of the respondents).

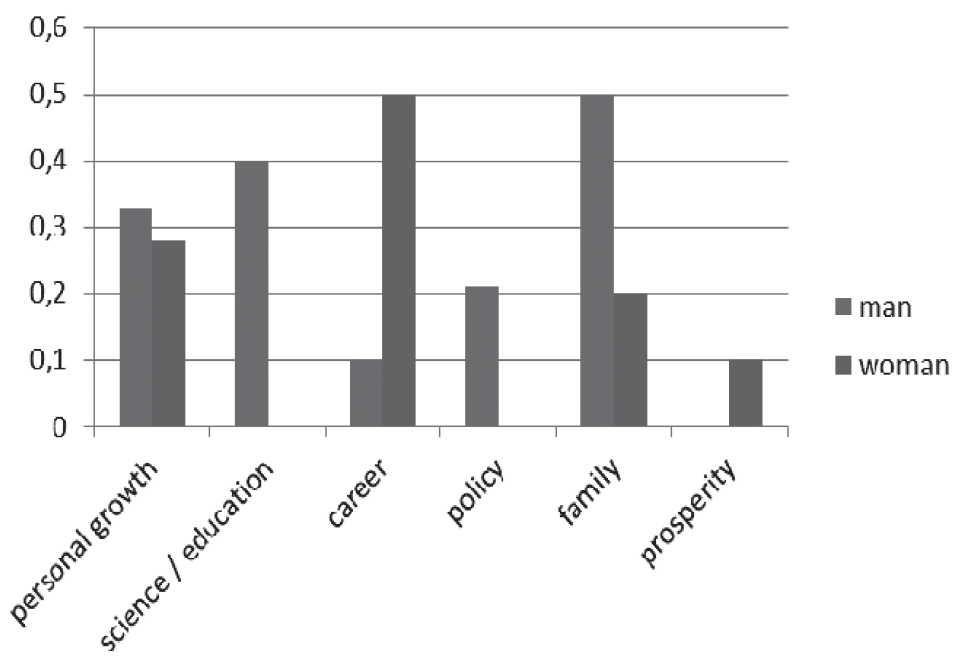

Figure 2. Areas in which it is necessary to make changes, according to the opinion of the respondents

Respondents also identified in which areas of their lives they are making changes themselves. The girls tolerate changes in personal growth $(50 \%)$ in the first place, in the second place - the changes in the working process $(37.5 \%)$, and in third place - the changes in the relationship between people, including family $(12.5 \%)$. Young men identified the following preferences: building a career $(53.3 \%)$, making changes in their lifes $(39.3 \%)$, and also personal growth and perception of the world $(16.7 \%)$. 


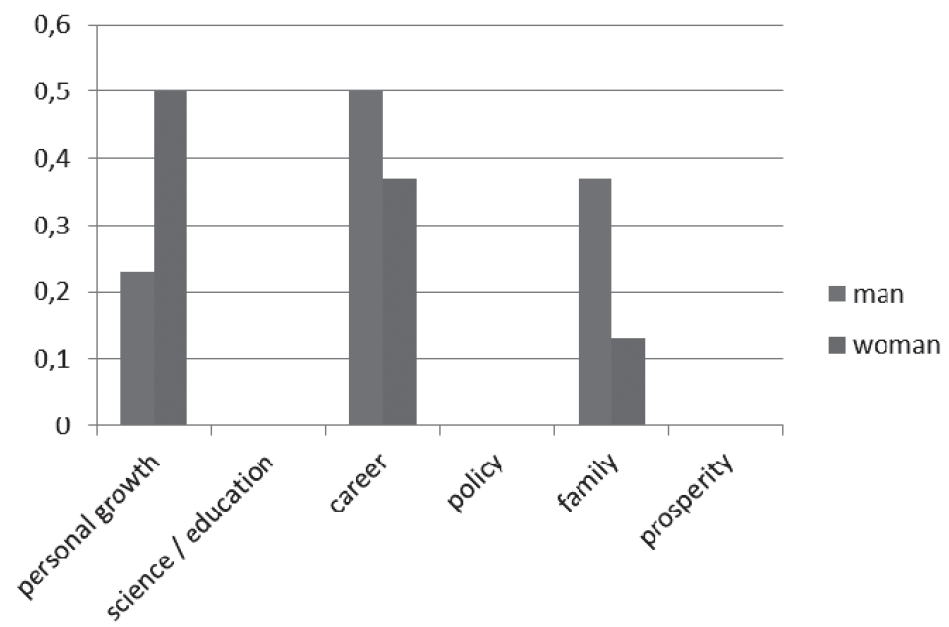

Figure 3. Spheres of life in which the respondents are making the necessary changes themselves

The main motives of innovative behaviour are the desire for a personal growth $(51.5 \%)$, the desire to build a career and to be a qualified specialist $(22.4 \%)$, the interest in life and science $(20.3 \%)$.

The part of the students surveyed $(16.7 \%)$ expressed a passively negative attitude to innovation. Also, respondents do not believe they need to change something, because it is not known what it may lead to.

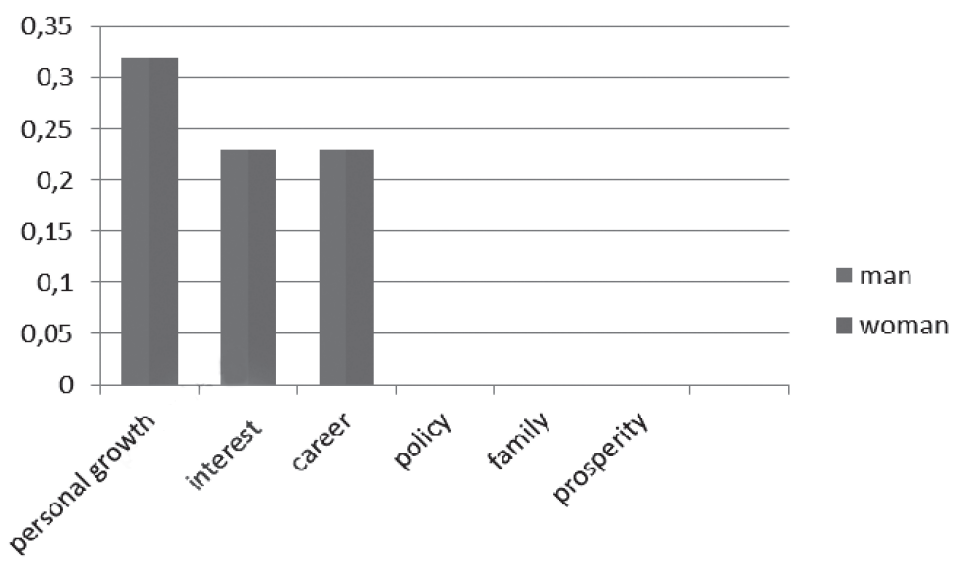

Figure 4. Motives of the innovative behaviour of the students of the architectural faculty of St. Petersburg State University of Architecture and Civil Engineering

The present study was aimed to study the attitude of future architects towards innovation. Overall, the majority of participants $(77.8 \%)$ expressed a positive attitude both to changes in the world in general and its separate components - the enrichment of the culture of the country, prolonging of the life, the increase of comfort, the realiSation of the abilities of gifted individuals. The results of this research to further strengthen our earlier studies (Artemeva, 2012). 


\section{Conclusion}

Some value orientations of the students of the architectural faculty of St. Petersburg State University of Architecture and Civil Engineering and their attitudes to innovation were identified in this study.

According to our previous theoretical (Ganz, 2009; Highsmith, 2009, Patton, 2011) and experimental (Artemeva, 2013) studies, it is possible to highlight the following major factors, which influence the innovation process:

1) a knowledge aspect;

2) a responsibility aspect;

3) a branch factor;

4) a social aspect;

5) a personal aspect.

But this research shows that future architects show importance a knowledge aspect, social and personal aspect. The branch factor and the aspect of responsibility are not that important for them.

We consider this fact as a dangerous one. Architects are in many respects responsible for the environment, including the safety of the existence of mankind in general and each person separately, in other words, they influence a sustainable development of the society in general vigorously.

Thus, in our opinion, architectural education should include a study of epy innovation activity, epy understanding of professional responsibility for the society in general, and for the clients, colleagues and the organization in particular. The data, which were obtained, are included in a curriculum of elective course "The psychology of creativity" (Artemeva, 2013). We consider it as one more step to the creation of sustainable development of higher education.

\section{References}

Abedalaziz, N. (2012). Related DIF in cognitive components of solving routine problems. The International Journal of Educational and Psychological Assessment, 10(2), 45-63.

Andreas, W., \& Strannegård, L. (2014). Developing researching managers and relevant research - the 'executive research programme'. Innovations in Education and Teaching International, 51(4), 411 - 424.

Artemeva, V. (2012). К вопросу о качествах личности, стремящейся к инновациям [To a question on qualities of the person aspiring to innovations]. Педагогическое пространство вуза: технологии, смыслы, ценности [Pedagogical space of higher education institution: technologies, meanings, values] (pp. 18-20). Saint-Petersburg: Saint-Petersburg State University of Architecture and Civil Engineering.

Artemeva, V. (2013). Innovations in technical education. In U. Harkonen (Ed.), Reorientation of Teacher Education towards Sustainability through Theory and Practice. Proceedings of the 10th International JTEFS/BBCC Conference Sustainable Development. Culture. Education (Vol. 7, pp. 246-252). Joensuu: University of Eastern Finland.

Autio, E., Kenney, M., Mustar, P., Siegel, D., \& Wright, M. (2014). Entrepreneurial innovation: The importance of context. Research Policy, 43, 1097-1108. 
Ganz, M. (2009). Why stories matter: The art and craft of social change. Retrieved December 12, 2014, from, http://www.sojo.net/index.cfm?action=magazine. article $\&$ issue $=$ soj0903\&article $=$ whystories-matter

Godlinik, O., \& Obozov, N. (2001). Учебный словарь по социальной педагогике [Educational dictionary on social pedagogy] (pp. 127-128). Saint-Petersburg: Oblik.

Highsmith, J. (2009). Agile project management: Creating innovative products. Boston: Addison-Wesley Professional.

Kirton, M. J. (2003). Adaption and innovation in the context of diversity and change. London: Routledge.

Lesovichenko, A. M. (2008). Современные духовно-нравственные проблемы студентов [Modern spiritual and moral problems of students]. Художественная культура и образование: теория, история и методика [Art culture and education: Theory, history and technique], 1, 14-20.

Patton, M. Q. (2011). Developmental evaluation: Applying complexity concepts to enhance innovation and use. New York: Guilford Press.

Plotinskiy, M. (2001). Модели социальных процессов [Models of social processes]. Moskva: Logos.

Sovetova, O. S. (1997). Инновации: теория и практика [Innovations: Theory and practice]. Saint-Petersburg: Saint-Petersburg State University.

Salīte, I., Gedžūne, G., \& Gedžūne, I. (2009). Educational action research for sustainability: Seeking wisdom of insight in teacher education. Journal of Teacher Education for Sustainability, 11(2), 14-30. doi: 10.2478/v10099-009-0037-y

Veselova, E. K. (2012). Нравственные аспекты формирования профессионализма у студентов вуза [Moral aspects of forming professionalism in students of higher school]. Педагогическое пространство вуза: технологии, смыслы, ценности [Реdagogical space of higher education institution: technologies, meanings, values] (pp. 57-62). Saint-Petersburg: Saint-Petersburg State University of Architecture and Civil Engineering.

Yushkov, S. А. (2008). Инновационные стратегии развития индивидуальности и общества [Innovation as a strategy for the development of individuals and society]. Известия российского государственного педагогического университета им. А.И. Гериена [News of the Herzen State Pedagogical University of Russia], 54, 275-277.

Yagolkovsky, S. R. (2010). Психология инноваций [Psychology of innovations]. Moskva: Higher School of Economics. 